\title{
Afterword: They say the Centre cannot hold: Austerity, crisis, and the rise of anti-politics
}

\author{
Ana Drago ${ }^{1}$ \\ Centro de Estudos Sociais da Universidade de Coimbra/CES-Lisboa, Portugal
}

\begin{abstract}
This afterword engages in a dialogue with the theoretical prospects opened by this Special Issue. First, it discusses how these articles show that conceptualizations such as anti-politics that aimed to organize a reading on the growing mistrust and disenchantment towards the institutional apparatus of contemporary democracies must not be equated to political voidance - I argue that these articles rather point to a profound legitimization crisis of the political-spatial consensus of neoliberal governance that, as this SI sustains, must be analyzed through the social and geographical configurations of the austerity cycle of the last decade and the situated conflict confronting it. In that sense, anti-politics redefines traditional conflict in liberal democracies, although through contradictory forms: commoning; radical protest; or ethno-nationalist extremism. And secondly, I discuss a most relevant argument that runs through the SI: analysis of anti-politics must engage with everyday spatial practices and geographical imaginaries that point where conflict arises, but also how it is being recrafted. I discuss this proposal of a spatial turn on anti-politics by interpreting it as emerging from the collapse of the aspirational narrative of neoliberalism - its promise of a global post-class conflict order succumbed as post-2008 austerity punitively targeted specific geographies, spaces and social classes, leading to a cycle of politicization organized through spatial or geographical dichotomies: North/South Europe; urban versus periurban/rural; streets versus institutions. After decades of neoliberal depoliticization of class conflict, attempts to relaunch anti-systemic political conflict seem to rely (again) on everyday spatial practices and geographical categories.
\end{abstract}

Keywords Antipolitics, austerity, politicization, crisis

\section{Heavy concepts are too lightly thrown}

Concepts such as anti-politics, post-democracy and post-political have become central in critical theory during the last decade drawing our attention to a dual process. First, a widely perceived disenchantment and increased mistrust of large popular segments with the political and institutional form of contemporary liberal democracies (Fawcett et al., 2017; Hay, 2007; Mair, 2013); and, secondly, a dismissal of transformative alternatives from the realm of political possibilities that seems to result from a persistent entanglement of democratic regimes with a neoliberal agenda (Crouch, 2004; Swyngedouw, 2011). Although relying in different dimensions, these processes tended to be discussed through the lenses of concepts such as antipolitics or post-democracy as a broad process of depoliticization within contemporary democracies - on the

${ }^{1}$ Corresponding Author: Ana Drago, Centro de Estudos Sociais da Universidade de Coimbra/CES-Lisboa, Picoas Plaza - Rua Viriato, 13 Lj 117/118, 1050-227 Lisboa, Portugal. Email: drago.ana@gmail.com 
one hand, reading depoliticization as an erosion of political affiliation with liberal democracy as it "actually exists"; on the other hand, seeing depoliticization as a deliberate exclusion of transformative movements from the realm of legitimate democratic conflict (Wilson and Swyngedouw, 2014).

This special issue goes to the core of the theoretical debates that have surrounded these interpretations and conceptualizations. Coming from multiples "locations", the perspectives included in this SI interrogate antipolitics and its account of the political configuration of our troubled times. Briefly, one can say that these different analysis depart from a shared discomfort with some analytical blind spots that these concepts seem to display and, more relevantly, they offer us a theoretical insight that has relevant implications on how to approach the political processes that anti-politics aims to discuss, and on how to put them to work for analytical purposes.

The shared discomfort with these "heavy concepts" of anti-politics and its counterparts arises from the difficulties they present when one faces the multiple, complex, and sometimes contradictory practices/languages of conflict that have emerged over the last decade. As an old love song from The Smiths used to say, such heavy words (concepts) should not be thrown too lightly - anti-politics, post-democracy or post-political can hardly stand for a univocal trend towards depoliticization, let alone to argue for an overall political voidance. Quite the contrary: politics, or the political, seem to have returned. We have gone through a decade marked by a most relevant cycle of protest and witnessed the rise of new political actors confronting different elements of the traditional political consensus that shapes contemporary democratic regimes. On the other hand, as some articles within this SI suggest, we also saw the rise of more "ordinary" and everyday political practices that, despite seeming less heroic than exemplary and voluntarist confrontation, are challenging the established political consensus.

In a sense, the views collected in this Special Issue seem to offer a two folded strategy. First, to interrogate anti-politics from the perspective of situated and uneven configurations of austerity that has been deployed within the last decade. And secondly, to argue that the discussion on situated forms/processes of depoliticization must be theoretically met by a research on situated and spatialized processes of (re)politicization. This analytical path goes well beyond an if-this-then-that approach - if austerity then conflict - which, although relevant, is not enough to grasp the profound transformation that seems to be unfolding in the last decade. So, going beyond is translated into a most relevant analytical path: authors in this SI engage in a fine-grained analysis of political change through an account of the spatial practices and geographical imaginaries that come to sustain and constitute these processes of depoliticization and repoliticization. It is a most relevant proposal: to engage with a spatial perspective that allows us to grasp not only "where" depoliticization-repoliticization is happening, but "how" anti-politics, austerity and crisis are being crafted by summoning geographical imaginaries and through an array of spatial practices that are constitutive of austerity, crisis and anti-politics.

This is a valuable theoretical insight for our times. First, because it offers a perspective that "decentres" debate and analysis on politicization-depoliticization from the measuring yardstick of traditional formal political realm. From the point of view of "the centre" - the institutional political apparatus - political crisis may look like voidance from the designated formal politics or as desertion from traditional political parties. However, it is precisely because this "disaffection" exhibits a confrontation - radical or reactionary - with the formal political system, that they need to be analysed within their own generative context, by considering their situated configuration within the cycle of austerity that marked the last decade. And secondly, as the analysis developed in this SI show, because spatial practices and geographical imaginaries are not merely the stage for the re-enactment of conflict/historical change, rather they are constitutive elements/processes that sustain the often contradictory political practices and identities that have emerged, grounded as they are in the uneven geography of austerity of the last decade.

Following these insights, I would like to discuss these proposals through a two steps reflection. First, I would like to propose a reflection on the ideological dimensions of austerity in its relationship with the legitimization narrative of the political centre. I argue that austerity shattered the ideological narrative of a global post-class 
order that, although already immersed in a latent crisis throughout the 2000's, still legitimized the (neo)liberal centre. In that sense, anti-politics should be read as the political configuration of a most relevant crisis of legitimization that became visible with the arrival of austerity politics. I use this crude expression of political centre to designate the narrative/political arrangement that entangled western democratic regimes with a proneoliberal agenda, and that have redesigned the role of state, public policies, and modes of governing throughout the last four decades. In good company, I take neoliberalism as deliberately aiming at depoliticization - that is, "to remove the politically contested character of governing" (Burnham, 2014: 189; Foster et al., 2014) through a reconfiguration towards techno-managerial governance and exclusion of transformative alternatives. But I interpret this process of depoliticization as resting mainly on an inspirational neoliberal narrative of inclusion - its promise of a post-class (conflict) world sustained on social mobility, access to property, cultural order, and a dominant position within a globalized economy, and that was pledged to large social segments; and, although I will not discuss it here, I take this idealization not merely as political promise, but as grounded in structural changes such as deindustrialization and financialization of western economies, that had a uneven geography and a structural impact in the configuration of social classes.

My main point is that after the 2008 Financial Crisis, austerity policies have inflicted a non-patchable breach on that aspirational promise of a post-class order. After 2008, austerity was deployed as an array of socially broad punitive discourses and policies that targeted not only the "underserving poor", or the "outdated" industrial workforce as it did in the 80's, but also those who the political centre used to consider the "normal" (popular and middle) classes. In that sense, present-day legitimization crisis of the political centre is the rupture of their promise of a post-class order. Austerity brought socially violent policies that (also) fell upon the social segments that aimed to remain/achieve a place in the "middle" social hierarchies. Perspectives on loss of status and downward mobility are central to read contemporary modes of both radical and reactionary repoliticization of social segments that have no "class language" or need to recreate it in new terms. Yates poem - the centre cannot hold - serves here as metaphor to signal a double systemic crisis: an ideological crisis of the political centre and a social crisis of these segments that saw themselves in the middle of social hierarchies.

And secondly, drawing on the different debates and analysis that compose this SI, I'll argue that the enduring consequences of this (depoliticizing) narrative of a post-class order are, in fact, what makes geographical imaginaries and spatialized political practices even more relevant in our present days. Geographical imaginaries and spatial practices have always been constitutive of political conflict. But in the recent austerity cycle, political geography offered categories that were used to justify and (unevenly) deploy different amounts of austerity within the EU and, after decades of post-class ideology, they are also the arenas/imaginaries available to launch processes of repoliticization. Grounded in the political geography of austerity, spatial practices and geographical imaginaries should not be interpreted just "where" anti-politics is rising, but rather how anti-politics is crafted after the effectiveness of several decades of post-class ideology.

\section{Anti-politics: Disaffiliation or anti-liberal repoliticization?}

Twenty years ago, on the eve on the new millennium and a decade after the "fall" of 1989, the triumph of neoliberal capitalism seemed unchallenged. Things were not quiet, though. In 1999 an urban battle spread through the streets of Seattle, coordinated by radical activists contesting the neoliberal agenda set for the negotiations of the Millennium Round of the World Trade Organization. These urban riots were the birthmark of the anti-globalization/alter-globalization movement that, in the years that followed, went on to organize social fora and stalk neoliberal summits, connecting Genoa to Porto Alegre, Chiapas to Gleneagles. Meanwhile, in the exact same year and on the opposite political spectre, the far-right party FPO managed to come in second in Austria's election, latter to become became part of the government and breaking the "cordon sanitaire" that usually excluded the far-right from governments of European Union members-states.

I bring to mind the tumultuous year of 1999 to point that the political and spatial consensus of liberal democracies and neoliberal globalization has been continuously challenged over the last two decades either by radical political action on the streets, or through the rise of ethno-nationalist far-right parties on the ballot 
boxes. However, at that time, we did not reach for such "heavy" concepts as anti-politics to describe both the possibilities and the perils posed by these events.

Concepts such as anti-politics, post-politics or post-democracy only emerged a few years later. They aimed to discuss a sense of fragmentation of the traditional forces that participated in the spatial and political consensus of the political centre - a widening disenchantment, mistrust, and disengagement of significant social segments from the institutional machinery of contemporary liberal democracies as they "exist". Anti-politics gains usefulness not as merely as a challenge of formal practices of institutional democracies, but rather a major political shift: the weakening of the ideological authority, a faltering of the political centre that results in a qualitative change in contemporary regimes.

This present-day difference must then be read against the political configuration of crisis that marked the last decade - that is, the profound impact of the recent round of austerity policies that followed 2008's financial crisis. As the discussion on this SI points, it is through the geography of austerity and its discontentment that anti-politics gains analytical purchase, pointing us to see where and how the "central" political consensus and its spatial arrangements are now being challenged and eroded. In a nutshell: to account for both political fragmentation and repoliticization, the how and the where are analytically indivisible.

\section{Austerity - A crisis of the aspirational middle?}

This story has been told before (Harvey, 2005) but allow me to bring back Fukuyamás The End of History to discuss the popularization of neoliberal parties, that provided them a stable ground for the making of the neoliberal democratic consensus (Fukuyama, 1992). Published in 1992, Fukuyama's book is probably one of the most exemplary specimen of a contemporary liberal utopia, presenting itself as the intellectual refinement of the ideological consequences of end of Cold War - an elegant enunciation of what Mrs. Thatcher had so rudely announced: there is/was no alternative. Significantly, Fukuyama's art laid not in making a passionate defence of market ideology, but rather in evicting class conflict from "the making of history" and resting his entire intellectual tour de force on an unproblematized and predefined strategic role of the middle classes. Not that Fukuyama actually discusses them; on the contrary, he assumes apriori that middle classes are both the product and the stronghold of liberal democracies - the embodiment of social mobility, private property, freedom and recognition that, so the argument went, only capitalism and liberal democracy could allow. The "middle" strata were broadly understood as ranging from the non-politicized working classes to the shores of the elites; a broad social alliance that could stand as a cornerstone for mingling democracy and capitalism in stable regimes - the buffer, the reasonable classes that could defeat both the socialist inspired working-class movements and the elites' authoritarian temptations.

From the ballot-box perspective, it seems that this inspirational narrative of the middle classes was successful in advanced democracies. From the 1980's forward, the so-called new right presented itself not (only) as the voice of a ruthless market; rather, in their situated political battles, repeatedly assumed the role of the representatives and enablers of the middle classes - arguing for their protection against tax "pillage" of the bureaucratic state; and condemning economic policies that either protected what was then named as obsolete industries, or "wasted" their hard-earned contributions on the "undeserving poor". They also set in motion an array of policies that directed the middle classes to access property, namely through vast privatizations of public housing and by fostering homeownership as a major driver of both financialization and ideological conformation - Thatcher's Right to Buy is paradigmatic of this dimension (Gray, 2018; Madden and Marcuse, 2016). And, finally, claiming that instead of redistribution, it was merit and technological progress that could provide social inclusion - educational skills and "clean jobs" in the service and financial sectors were the main elements of economic progress and individual welfare. This promise of social mobility, service economy and (home)ownership was a most accomplished tool of depoliticization of class antagonism in post-cold war period.

By the mid-90's, this post-class narrative was covered with a gleaming new layer: the lexicon of a felicitous globalization, presented by the protagonists of the liberalization wave that swiped socialist and social- 
democrat parties in western democracies. The Millennium Round of 1999 was their golden moment - they governed the USA (Clinton), the UK (Blair), Germany (Schroeder), France (Jospin), Italy (D'Alema) and Portugal (Guterres), among others. Global liberalization was now supported by parties that once represented working class, and presented through a cosmopolitan image - the new promise of inclusion and mobility was crafted through a narrative of a desirable future led by a flexible, urban, educated and culturally post-national middle classes. Through education skills and merit, homeownership and global cultural perspectives, the political and spatial centre/consensus built his legitimacy in liberal democracies.

This is not the place to discuss in detail the mischiefs of neoliberal globalization and its post-class order. My point is that it was after the 2008's Great Financial Crisis that this inspirational narrative was shattered. Austerity came as a punitive discourse that draw a specific geography of nations and regions, sorting the truthful from the faulty ones; and as disciplinary policies that targeted well beyond lower or working classes.

First, austerity was presented as global rationality against the flaws of certain nations, certain geographies, and certain classes. As Stranding (2019) shows in this SI, austerity policies invoked a rationality that was presented as objective because it was built from the outside of democratic representation: experts argued that "the markets", "the global economy", the international institutions "proved" the unsustainability of redistributive policies. Social spending and public debt became central within the conflicts among countries in the Euro Crisis; but also household debt proved the irresponsible private consumption habits of middle segments, although much of it resulted from homeownership policies and cheaper credit encouraged by the Euro Monetary System since the mid-90's. Recession, stagnation, and private and public debt were portrayed as the result of the "normal" classes and countries that have being living above their means. Posed as evidence, coming from assessments of "neutral" entities outside the democratic political arena, the agenda of austerity was presented as moral condemnation and a disciplinary remedy of nations, regions, and classes.

Secondly, austerity abandoned any suggestion of cosmopolitan/post-national inclusion nor protection of "normal" popular and middle classes. Multiple sociological studies that have signalled this crisis of prospects within social segments that begun to perceive themselves as losing their middle positions and/or prospects of future in the 2000's, namely low-paid working classes and younger generations, as rampant labour precarity emerged, along with lowering incomes, housing crisis, and a changing world with no foreseeable improvement - what Nachtwey (2018) called "societies of downward mobility"; what Guilluy (2014) named as la France périphérique, almost predicting the yellow-vests confrontations, to signal the political crisis within the periurban territories deprived both from industry jobs and the (precarious) work opportunities of metropolitan regions; and also López (2016) entitles his account on Indignados movement in Spain as "the sunset of the middle class politics". The geographical and ideological shape of austerity sealed the fate of an already simmering crisis of the prevailing political and spatial consensus. This crisis of the political centre is, then, a crisis of the post-class order/global middle class, arising as ethno-nationalism against submersion in liberal globalization, or as radical and commoning alternatives. If the middle cannot hold, the centre will not hold.

Curiously, Fukuyama seems to know this. He recently acknowledged the collapse of his promise of an inclusive post-class liberal order, signalling the rise of inequality and exclusion. He argues that the erosion of the legitimacy of liberal democracies is the elites' fault (Fukuyama, 2018). Not surprisingly from his ideological angle, blame lies with traditional left parties that have replaced the discourse on class inequalities with the so-called identity politics, rendering the impoverished segments of traditional working classes politically invisible, and denying representation to the despaired "normal" middle classes that depend on wages and public services so secure their status. Evidently, Fukuyama does not call of the return of class antagonism nor redistributive policies. Rather, he argues that salvation for capitalism and liberal democracy lies on a "new creed": an assimilationist nationalism.

This is a most surprising proposal for a liberal globalist. But, nonetheless, it poses a view worth discussing: can political categories of geography suture the crisis of the political categories of economy? Could the nation mend the effects of the shattering of global/post-class promise inflicted by austerity? Can geo-political imaginaries repair the depoliticization inflicted on class antagonism? 


\section{Politicizing austerity: Generative spatial practices and geographical imaginaries}

More than 30 years ago, Wallerstein, Arrighi and Hopkins revisited the classic debate of class versus nation within the making of anti-systemic movements, noting that during the second half of XXst century the political movements that enmeshed class and nation were quite successful (Arrighi et al., 1989). Social-democrats came to rule western democracies in the post-War decades; the communist states prevailed in the East until that year of 1989; and national-socialist liberation movements achieved victory against colonialism from the mid-1940's forward. Within that historical context, the mixture of class and nation proved to be a reasonable strategy because both socialism and nationalism shared a common objective: the seizure of state power.

Their reflection signals that political geography and political economy have always mingled in the production of conflict. However, the relevant question for our times is to ask if the defeat of the traditional class antagonism after 1989, and after decades of post-class globalization ideology, new forms of antagonism are being recrafted through spatial and geographical categories. In my view, the debates and analysis collected in this SI point that the effects of this long cycle of depoliticization of class antagonism are precisely embodied in the relevance of spatial practices and geographical imaginaries to generate political conflict.

In that sense, the articles collected in this SI advocate a "spatial turn" to read anti-politics by offering a compelling argument that spatial practices and geographical imaginaries have become strategic political devices to launch processes of repoliticization - either progressive or reactionary forms of resistance/opposition to austerity. Beverigde and Koch (2019) show how spatial practices entrenched in urban everyday challenge local state apparatus and privatization policies; Habermehl (2019) shows us how situated autogestion politics emerge during austerity in Buenos Aires, allowing everyday antagonist practices to settle in; Förtner et al. (2020) point to the revival of the politicization of the urban-rural divide which, as the future, is not what it used to be; Featherstone (2019) discusses the entanglement of the spatial forms of austerity and the geographical imaginations of resistance, pointing to the relevance of the struggles of nations against multinational states within the framework of an uneven geographical deployment of austerity; Dönmez (2020) point to how austerity became authoritarian within the "borderlands" of Europe, rendering visible the core contradictions between capitalism and the liberal state and leading to a situated cycle of radical struggles; Karaliotas (2019) takes us through the squares' movement in Greece as form/moment of the political to emerge, aiming to represent a multitude that constitutes the nation against crippling austerity imposed by transnational institutions. Taken together, these analysis provide an analytical path for reading anti-systemic conflict as it is being remade through spatial-geographical categories: North versus South in the European Debt crisis; situated spaces of everyday antagonism; urban versus rural (the far-right rise); urban politicized sociability against the local state; "austeritarian" governance deployed in the borderlands of liberal Europe; deindustrialized regions against service/financialized metropoles (Brexit); squares versus parliaments and/or transnational institutions (Greece, Portugal or the Spanish $15 \mathrm{M}$ ).

We seem to be witnessing nothing less than an array of processes of reconstitution of political subjectivities. Promising or dangerous configurations of antagonism are being recrafted through spatial practices that deliberately mobilize geographic imaginaries to articulate emancipatory or reactionary configurations of "the people" against what is conceived as a captured democracy. One cannot foresee the consequences these processes - but still, we come to the end of this SI bearing theoretical and analytical tools to analyse and discuss what comes ahead.

\section{Acknowledgements}

Comments by Ross Beveridge significantly improved this essay. Remaining errors are the author's own.

\section{Declaration of conflicting interests}

The author(s) declared no potential conflicts of interest with respect to the research, authorship, and/or publication of this article. 


\section{Funding}

The author(s) received no financial support for the research, authorship, and/or publication of this article.

\section{ORCID iD}

Ana Drago https://orcid.org/0000-0002-9148-3380

\section{References}

Arrighi, G, Hopkins, T, Wallerstein, W (1989) Antisystemic Movements. London: Verso Books.

Beverigde, R, Koch, P (2019) Contesting austerity, de-centring the state: Anti-politics and the political horizon of the urban. EPC: Politics and Space. Epub ahead of print 31 August 2019. DOI: $10.1177 / 2399654419871299$.

Burnham, P (2014) Depoliticisation: Economic crisis and political management. Policy \& Politics 42(2): 189206.

Crouch, C (2004) Post-Democracy. Cambridge: Polity.

Dönmez, P (2020) Against austerity and repression: Historical and contemporary manifestations of progressive politicisation in Turkey. EPC: Politics and Space. Epub ahead of print 6 May 2020. DOI: $10.1177 / 2399654420920291$.

Fawcett, P, Flinders, M, Hay, C, et al. (eds) (2017) Antipolitics, depoliticization and governance. Oxford: Oxford University Press.

Featherstone, D (2019) From out of apathy to the post-political: The spatial politics of austerity, the geographies of politicisation and the trajectories of the Scottish left(s). EPC: Politics and Space. Epub ahead of print 11 December 2019. DOI: DOI:10.1177/2399654419885706.

Förtner, M, Belina, B, Naumann, M (2020) The revenge of the village? On the geography of right-wing populist electoral success, anti-politics, and austerity in Germany. EPC: Politics and Space. Epub ahead of print 2 September 2020. DOI: 10.1177/2399654420951803.

Foster, EA, Kerr, P, Byrne, C (2014) Rolling back to roll forward: Depoliticisation and the extension of government. Policy \& Politics 42(2): 225-241.

Fukuyama, F (1992) The End of History and the Last Man. New York: Free Press.

Fukuyama, F (2018) Against identity politics. The new tribalism and the crisis of democracy. Foreign Affairs (5): 97.

Gray, N (2018) Introduction: Rent unrest: From the 1915 rent strikes to contemporary housing struggles. In: Gray, N (ed.) Rent and Its Discontents: A Century of Housing Struggle. London: Rowman and Littlefield, pp. xvii-xxxix.

Guilluy, C (2014) La France Périphérique. Comment on a Sacrifié Les Classes Populaires. Flammarion.

Habermehl, V (2019) Everyday antagonisms: Organising economic practices in Mercado Bonpland, Buenos Aires. EPC: Politics and Space. Epub ahead of print 12 November 2019. DOI: 10.1177/2399654419887745. 
Harvey, D (2005) A Brief History of Neoliberalism. New York: Oxford University Press. Hay, C (2007) Why we Hate Politics. Cambridge: Polity.

Karaliotas, L (2019) Geographies of politics and the police: Postdemocratization, SYRIZA, and the politics of the "Greek debt crisis". EPC: Politics and Space. Epub ahead of print 19 September 2019. DOI:10.1177/2399654419876650.

López, ER (2016) La Política en el Ocaso de la Clase Media. El Ciclo 15M-Podemos. Madrid: Traficantes de Sueños.

Madden, D, Marcuse, P (2016) In Defense of Housing. The Politics of Crisis. London: Verso Books.

Mair, P (2013) Ruling the Void: The Hollowing of Western Democracy. London: Verso. Nachtwey, O (2018) Germany’s Hidden Crisis: social Decline in the Heart of Europe. London: Verso Books.

Stranding, A (2019) Relational expertise and the spatial (re)production of austerity: Challenges and opportunities for progressive politics. EPC: Politics and Space. Epub ahead of print 5 September 2019. DOI:10.1177/2399654419873674.

Swyngedouw, E (2011) Interrogating post-democratization: Reclaiming egalitarian political spaces. Political Geography 30: 370-380.

Wilson, J, Swyngedouw, E (eds) (2014) The Post-Political and Its Discontents: Spaces of Depoliticisation, Spectres of Radical Politics. Edinburgh: Edinburgh University Press.

Ana Drago is a researcher at Observatory of Crisis and Alternatives of the Centro de Estudos Sociais/University of Coimbra, Portugal. She holds a PhD in Urban Studies by ISCTE-Instituto Universitário de Lisboa and Universidade Nova de Lisboa. Her work has focused mainly on the relation between politicization and the urban, and recently on the political consequences of the financialization of housing/the city in the aftermath of the 2008's global financial crisis. She was a member of the Portuguese Parliament for the Left Bloc, from 2002 to 2013. 